\title{
Does Sustainability Pay Off for European Listed Real Estate Companies? The Dynamics between Risk and Provision of Responsible Information
}

Authors Marcelo Cajias and Sven Bienert

Abstract We follow the guidelines of the Global Reporting Initiative and the European Public Real Estate Association to investigate the quality of real estate-related sustainability information provided by European listed real estate companies in 13 countries. We find that human resources and stock price volatility play a significant role in the company's strength with respect to corporate social responsibility (CSR) activities. Business complexity and financial transparency enhance the provision of sustainable information to capital markets, but business experience does not appear to affect the decision "to go CSR." Furthermore, the benefits of ex ante responsible activities are reflected in lower levels of idiosyncratic risk, but only for firms providing clear signals to investors and markets.

Over the last decade, socially responsible activities and sustainability in a broader sense have been successfully integrated into corporate strategies and are now considered as an essential value-driver for the long-term success of listed or public companies. Corporate responsibility forces firms allocating resources to preserve a balance between environmental, social, and economical objectives, which may affect internal and external stakeholder groups. Companies maintaining this equilibrium require a socially responsible sustainability agenda, along with a description of short- and long-term action items. The purpose of this study is to identify the factors affecting the firm-specific decision to allocate resources into socially responsible activities and whether these corporate actions mitigate the firm's risk profile. We provide evidence that socially responsible activities are rewarded by investors and capital markets in a reduction of a company's idiosyncratic risk.

We have organized the paper as follows. The sections of the paper are split into the two research questions: the drivers of a responsible provision of information and the consequences of providing responsible information. The first section situates our research questions and hypotheses within the existing literature concerning sustainability and real estate. The second section describes our data. The third explains the econometrical methodology in order to explain the results 
in the fourth section. At the end we discuss our findings and present our conclusions.

\section{Literature Review}

Corporate social responsibility (CSR) has become a growing matter over the last ten years and its diffusion has already reached listed enterprises, non-government organizations, and inevitably real estate companies. Many concepts have been also developed to theoretically describe corporate sustainability activities, such as Environmental, Social, and Governance (ESG), CSR, and Socially Responsible Investment (SRI). Despite the conceptual differences across them, they describe the integration of responsible and environmental activities into a firm's core strategy in order to react to climate changes and globalization issues in general.

As a response to the increasing importance of sustainability, firms provided voluntarily supplementary information regarding their concerns and awareness to global changes. Sustainability principles, in accordance to the Global Reporting Initiative (GRI), are well known standards that enable the international comparison of firms' responsibility performance. The GRI framework is applicable to all sectors and since its foundation the number of sustainability reports has grown exponentially. In this context, real estate companies are important participants to the international development and implementation of sustainable policies. According to Nelson, Rakau, and Doerrenberg (2010), the construction and real estate industry has an enormous global impact and "accounts for $42 \%$ of the EU's final energy consumption and for about $35 \%$ of all greenhouse gas emissions."

Facing the fact that sustainability plays an important role in the real estate sector, due to the impact to future generations, it is essential to identify the key elements of sustainable activities, along with their economical benefits. The first subsection examines the mechanism that drives firms to allocate resources in sustainability, while the second subsection explores the economical consequences of the effective resource allocation.

\section{The Drivers of a Responsible Provision of Information}

Solow (1991) defines sustainability simply as "our obligation to future generations." In general, firms are active players in the implementation of global sustainability policies and mitigation of risks that affect future generations. Porter and Kramer (2006) delineate this approach as "license-to-operate" and explain that firms identify themselves with social and environmental concerns due to future global challenges. Otherwise, firms would be acting outside their "license" and would disappear. Roberts, Rapson, and Shiers (2007) show that the drivers of social responsibility are an internal adaptation to economic change such as customer demand, as well as an external response to poor ethical standards. Additionally, Falkenbach, Lindholm, and Schleich (2010) argue that real estate companies aim to invest in CSR to enhance their image to investors through the publication of sustainability reports. Furthermore, they conclude that external 
financial incentives and regulatory policies force companies to revaluate their core strategies.

A growing literature concentrates on the determinants of voluntary disclosure following the GRI guidelines. Among others, a debate arises concerning whether media visibility or media presence predicts the decision "to go CSR." Rationally speaking, the assumption that sustainability reports have an impact on corporate reputation and are a media instrument that reveals the positive and negative aspects of a firm's strategies could be right. Albers and Guenther (2010) concentrate on the determinants of disclosing the social reports of 600 European firms and conclude that social reports are likely to be published by high capitalized companies and by those adhering to sustainability indices. They suggest that media presence is not a determinant for firms "going CSR." Contradictorily, Gamerschlag, Moeller, and Verbeeten (2010) show that for Germany, higher media visibility increases the probability to disclose a CSR report. For the field of real estate, only a few European companies disclose GRI reports and the empirical evidence is small. Instead of examining media visibility, which highly correlates with size, we aim to expand the literature by analyzing if financial transparency determines CSR.

Sustainability includes the effective use of resources and an adequate substitution of resources to minimize consumption (Solow, 1991). For the field of real estate, it is essential to understand the benefits of property investments that consider energy-related, social, and environmental features. Fuerst and McAllister (2009, 2011), Eichholtz, Kok, and Quigley (2009a, 2009b), and Bienert et al. (2010) show that sustainable buildings in general pay off. These findings lead real estate companies to allocate sustainable buildings in their portfolios to force the reduction of energy consumption.

Following these results, companies allocate resources to CSR in order to remain competitive. It is also rationale to assume that real estate firms react to customer demand. This paper examines the real estate-specific characteristics that influence the intensity of sustainable and responsible activities.

\section{The Consequences of Providing Responsible Information}

Looking at responsibility and sustainability in order to reveal their link to economic performance requires a clear conceptual framework and definition of variables. A large body of meta-analyses examine if sustainability predicts financial performance (e.g., Orlitzky, Schmidt, and Rynes, 2003; Margolis, Elfenbein, and Walsh, 2007). Generally, they find evidence that firms with high levels of social and environmental performance enjoy enhanced financial performance and vice versa. Apart from several measurement effects, sector heterogeneity, and the sample period, these findings motivate firms allocating resources to CSR activities. On a corporate level, Porter and Kramer (2006) explain that socially responsible activities should have a positive impact on corporate value, preconditioned that their integration into the firm's core operational business is successful. Therefore, a sustainability agenda must not only cover vague strategies and goals, it must reflect a high awareness to social 
and environmental concerns. Following Surroca, Tribó, and Waddock (2010), corporate responsibility positively affects financial performance through the creation of intangible assets (i.e., sustainability not only enhances a firm's reputation, it can improve financial outcomes). They conclude that the more intensive and effective a firms' sustainability strategy, the higher will be the economic benefits.

Concerning the risk profile of companies investing in CSR, a growing body of literature provides evidence that sustainability in a broader sense is able to lessen firms' unexplained stock volatility. Luo and Bhattacharya (2009) found that corporate responsibility is able to generate stakeholder value and mitigate information asymmetry due to the enhanced provision of information. Information regarding the firm-specific sustainability agenda is a clear positive signal to capital markets and investors. Their results suggest that sustainability activities affect negatively the future unexplained stock volatility, decreasing the idiosyncratic risk. Lee and Faff (2009) argue that sustainability portfolios exert significantly lower levels of idiosyncratic risk, hence sustainability creates, beside the above explained effects, financial stability in terms of a better pricing mechanism (i.e., CAPM). Ferreira and Laux (2007) provide strong evidence that a well-developed corporate governance level also lessens the idiosyncratic risk and enhances the information about the distribution of expected cash flows. Following this result, we aim to provide empirical support that sustainable and responsible activities lead to lower idiosyncratic risk and consequently reduce the uncertainty of a firm's risk profile.

We believe that the existing real estate literature focuses to a major extent on the economic impact of responsible investments on a property-specific level. In this context, other sustainable real estate-specific activities that play an important role and might affect the overall value of the portfolio or company are a barely untouched research field. Therefore, our approach not only strengthens and supports the related literature on idiosyncratic risk, but also confirms the helpful consequences of responsibility at a company level.

\section{Data}

The data for our study are from SNL, Thomson Reuters Datastream, and annual reports. ${ }^{1}$ The sample includes European real estate listed firms for 2007 and 2008 that are incorporated in the Global Property Research Index 250 (GPR 250), excluding real estate funds. Our initial sample included 84 companies, from which four do not provide sufficient financial information in Datastream. The final sample includes 80 European real estate companies. The annual reports were obtained from SNL and the enterprise's web pages. All data are employed in a yearly frequency, except for the returns. We use daily returns for the closing day, in order to calculate the yearly mean return, along with our proxies for both estimation and idiosyncratic risk. All variables controlled for possible outliers at $5 \%$ and $95 \%$.

We are interested in the quantity and quality of socially responsible information for real estate companies. Our variables measure the firm-specific commitment to 
social responsibility in accordance with the European Public Real Estate Association (EPRA) and general sustainable reporting guidelines (GRI-G3). In order to derive our proxies for CSR, we use a questionnaire that has 13 questions and 26 points. Several studies have proxied sustainability using questionnaires. For example, Holder-Webb, Cohen, Nath, and Wood (2009) employ content analysis techniques to externally categorize the amount of information that fall into one of the main GRI-sustainability categories, whereas Plumlee, Brown, and Marshall (2008) concentrate on a separated corporate environmental report and apply an index scorecard to calculate the quality of disclosed information. Similar to these studies, we define the following four responsibility areas as: (1) human rights and social responsibility; (2) environmental responsibility; (3) investment/ financial responsibility; and (4) additional disclosure quality. Human rights and social responsibility strengths consider not only the extent to which rights are considered in the company organization, but also information about the company's cultural, diversity, and recruitment policy. The environmental responsibility covers procedures related to training and raising awareness in relation to environmental aspects, as well as information concerning emissions, waste, and materials. This area covers also the investment in sustainable buildings. Investment/financial responsibility asks whether the company is prepared for climate changes in economical terms, whereas the additional disclosure area covers at what level companies apply EPRA-Best Practices Recommendations. The former drives firms to run scenario analysis of the key performance indicators due to energy price fluctuation and is following the GRI a key factor for real estate companies (Exhibit 1).

In order to avoid time-embedded bias, three researchers read the annual reports independently and $14 \%$ of the reports were evaluated doubly to ensure the correctness. We assign 2 points when a firm discloses key performance indicators, 1 point for only explanatory information, and 0 for no information. Exhibit 2 presents the results of our sustainability survey. The values are calculated as the sum of the obtained points divided by the maximal achievable points. We breakdown our results by year, real estate sector, and sustainability area. Over 2007 and 2008, we found a constant sustainability agenda with levels under 50\%. European real estate investment trusts (REITs) present generally higher scores than non-REITs and present in 2007 high levels in the environmental and financial responsibility area. All firms present a high acceptance of the EPRA-BPR. Following the GRI, firms should model scenario analysis to determine the financial consequences of energy price fluctuations and weather disasters. Our survey shows low levels concerning environmental risks, which are essential in view of climate change and its associated costs. It is remarkable to establish constant sustainability levels in view of the economical cycle in 2007 and 2008. Surroca, Tribó, and Waddock (2010) propose that resource allocation to CSR activities preconditions a stable economical situation. Contradictory to this proposition, we observe a slightly increasing strength for sustainable and responsible activities across European real estate companies, particularly by REITs.

We derive two variables from our survey in order to explain the drivers and consequences of CSR. Therefore, we define our first variable $C S R_{i, t}^{\text {quality }}$ in dependence to the maximum number of score items as follows: 
Exhibit 1 | Sustainability Agenda for Listed Real Estate Companies

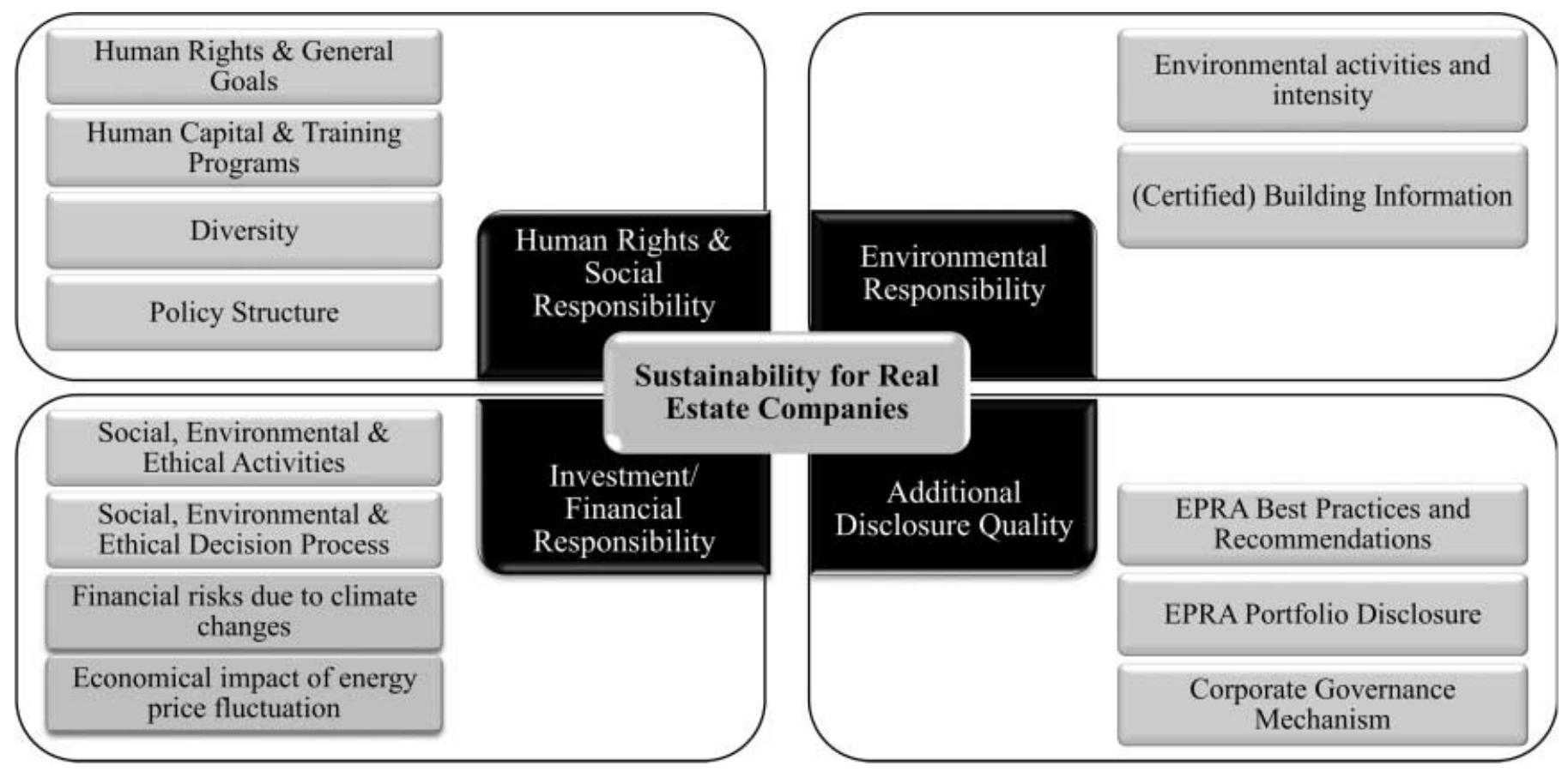


Exhibit 2 | Results of the Sustainability Survey

\begin{tabular}{|c|c|c|c|c|c|}
\hline \multirow[b]{2}{*}{ Sector } & \multicolumn{2}{|l|}{2007} & \multicolumn{2}{|l|}{2008} & \multirow[b]{2}{*}{ Overall } \\
\hline & Non-REITs & REITs & Non-REITs & REITs & \\
\hline Number of firms & 42 & 38 & 42 & 38 & \\
\hline All sectors & $\begin{array}{l}46.98 \% \\
(7.29)\end{array}$ & & $\begin{array}{l}48.26 \% \\
(6.42)\end{array}$ & & $47.62 \%$ \\
\hline Yearly & $\begin{array}{l}42.83 \% \\
(6.27)\end{array}$ & $\begin{array}{l}51.12 \% \\
(8.23)\end{array}$ & $\begin{array}{l}44.99 \% \\
(5.96)\end{array}$ & $\begin{array}{l}51.54 \% \\
(6.90)\end{array}$ & (6.85) \\
\hline $\begin{array}{l}\text { Responsibility Areas } \\
\text { Human Rights \& } \\
\text { Social Responsibility }\end{array}$ & $41.07 \%$ & $43.42 \%$ & $40.18 \%$ & $44.41 \%$ & $42.27 \%$ \\
\hline $\begin{array}{l}\text { Environmental } \\
\text { Responsibility }\end{array}$ & $44.05 \%$ & $61.18 \%$ & $44.05 \%$ & $54.61 \%$ & $50.97 \%$ \\
\hline Financial Responsibility & $27.08 \%$ & $41.12 \%$ & $31.85 \%$ & $29.93 \%$ & $32.50 \%$ \\
\hline $\begin{array}{l}\text { Disclosure and } \\
\text { Transparency }\end{array}$ & $59.13 \%$ & $58.77 \%$ & $63.89 \%$ & $77.19 \%$ & $64.75 \%$ \\
\hline
\end{tabular}

Notes: Percentage represents the sum of points relative to the maximal points. Standard deviations of points in parentheses.

$$
C S R_{i, t}^{\text {quality }}=\left\{\begin{array}{c}
2 \Leftrightarrow \Sigma(\text { Points })_{i, t}>Q_{77} \\
1 \Leftrightarrow Q_{33} \leq \Sigma(\text { Points })_{i, t} \leq Q_{77} \\
0 \Leftrightarrow \Sigma(\text { Points })_{i, t}<Q_{33}
\end{array}\right\}
$$

Companies whose overall score for the key performance indicators is quantitatively high belong to the highest category, $C S R_{i, t}^{\text {quality }}=2$. Companies that disclose only general goals and information belong to $C S R_{i, t}^{\text {quality }}=1$. The upper (lower) quintile was 18 and 17 (7 and 8) points for 2007 and 2008, respectively. We assign this ordered response category, as described by Davidson and MacKinnon (2004), in order to generate a latent variable. This approach enables us to investigate the independent factors that lead to more detailed and intensive CSR disclosure (i.e., the variables contribute to the highest information category). Because our focus also lies on the effects of CSR on idiosyncratic risk, we employ an exogenous proxy from our survey to explain the consequences of providing responsible information. $C S R_{i, t}^{\text {high }}$ takes the value of 1 for $C S R_{i, t}^{\text {quality }}=2$ and 0 otherwise. $C S R_{i, t}^{\text {low }}$ takes the value of 1 for $C S R_{i, t}^{\text {quality }}=1$ and 0 otherwise. We relax the assumption of information quality and generate a binary variable that contributes to the robustness check of our models. We assign $C S R_{i, t}^{\text {quantity }}$ to take the value of 1 , if the sum of items, independent of the information category, is higher than or equal to the median of all companies, and 0 otherwise: 


$$
C S R_{i, t}^{\text {quantity }}=\left\{\begin{array}{c}
1 \Leftrightarrow \sum(\text { Points })_{i, t} \geq Q_{50} \\
0 \Leftrightarrow \text { otherwise }
\end{array}\right\}
$$

$C S R_{i, t}^{q u a n t i t y}$ measures the overall amount of information independent of the disclosure category (i.e., regardless of qualitative and quantitative information). We use this specification to validate and enhance the veracity of our empirical survey. The 50\% quantile was 9.5 and 11 points for 2007 and 2008, respectively.

We estimate the idiosyncratic risk according to the Capital Asset Pricing Model (CAPM). Rather than taking the standard deviation of the daily residuals directly, we use the measures of Ferreira and Laux (2007). Therefore, we estimate asset pricing regressions with daily returns data within a two-year window. For each firm we calculate our measure for idiosyncratic risk $\Psi_{i, t}$ as:

$$
\Psi_{i, t}=\log \left(\frac{1-R_{i}^{2}}{R_{i}^{2}}\right)=\log \left(\frac{S S R}{E S S}\right),
$$

where $R_{i}^{2}$ is the coefficient of determination of each asset pricing equation. We estimate information risk using the accruals quality model of Francis, Lafond, Olsson, and Schipper (2005) with regional adjustment. Information risk arises from the unexplained matching between working capital accruals and operational cash flow. There is strong evidence of the accuracy of this variable as a proxy for information risk (e.g., Aboody, Hughes, and Liu, 2005; Francis, Khurana, and Pereira, 2005; and Ecker et al., 2006). High values of information risk communicate the poor quality of accruals (i.e., low-quality information to investors, thus low financial transparency). Our proxy for estimation risk is calculated as the logarithm of the standard deviation of the daily stock price for the last two years, divided by the mean of its price. Market value is calculated as the share price multiplied by the number of ordinary shares in issue. The number of employees, audit fee, and ROA are obtained either from Datastream or from the annual reports.

Exhibit 3 presents the descriptive statistics. The market value of our real estate companies is on average approximately at $\mathrm{e}^{13.156}=517^{\prime} 104.366$ Mio $€$ and is constant over 2007 and 2008. In order to prevent some heteroscedasticity problems, we use the natural logarithm and assume $1 €$ auditing fees. ${ }^{2}$ Concerning the age of European real estate companies, we observe firms that have been listed in the respective market since 1965, which means a maximum of 44.08 years at the end of September 2010. Information risk and estimation risk (Volat) are standard deviations that significantly positively correlate. The ROA is not constant over our observation period, because of the market-based response of the "financially poor" years, 2007 and 2008.

The sample contains only real estate companies (REITs and non-REITs) measuring financial performance with Funds from Operation (FFO), ${ }^{3}$ rather than 
Exhibit 3 | Descriptive Statistics

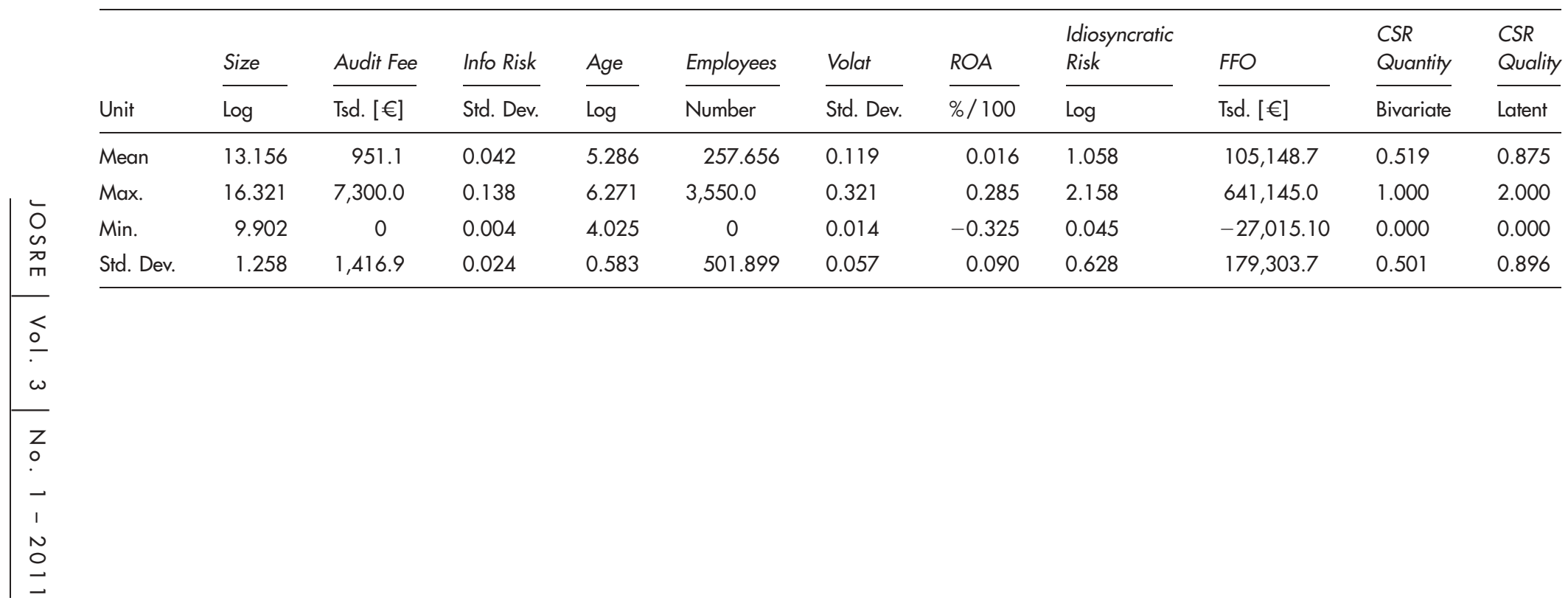


Exhibit 4 | Correlation Matrix

\begin{tabular}{|c|c|c|c|c|c|c|c|c|c|c|c|}
\hline & Size & Audit Fee & Info Risk & Age & Employee & Volat & $R O A$ & $\begin{array}{l}\text { Idiosyncratic } \\
\text { Risk }\end{array}$ & FFO & $\begin{array}{l}\text { CSR } \\
\text { Quantity }\end{array}$ & $\begin{array}{l}\text { CSR } \\
\text { Quality }\end{array}$ \\
\hline Size & - & & & & & & & & & & \\
\hline Audit Fee & $0.44^{*}$ & - & & & & & & & & & \\
\hline Info Risk & 0.02 & 0.07 & - & & & & & & & & \\
\hline Age & 0.15 & 0.16 & 0.07 & - & & & & & & & \\
\hline Employee & $0.48^{*}$ & $0.42^{*}$ & $0.25^{*}$ & $0.30^{*}$ & - & & & & & & \\
\hline Volat & $-0.17^{*}$ & 0.06 & $0.18^{*}$ & 0.14 & $0.22^{*}$ & - & & & & & \\
\hline$R O A$ & $0.18^{*}$ & -0.12 & $-0.18^{*}$ & -0.07 & -0.09 & $-0.35^{*}$ & - & & & & \\
\hline Idiosyncratic Risk & $-0.58^{*}$ & $-0.28^{*}$ & $0.16^{*}$ & 0.03 & $-0.32^{*}$ & -0.03 & -0.04 & - & & & \\
\hline FFO & $0.43^{*}$ & 0.09 & 0.06 & 0.03 & $0.38^{*}$ & -0.03 & 0.07 & $-0.43^{*}$ & - & & \\
\hline CSR Quantity & $0.40^{*}$ & $0.40^{*}$ & 0.02 & $0.16^{*}$ & $0.52^{*}$ & $0.25^{*}$ & -0.13 & $-0.43^{*}$ & $0.31^{*}$ & - & \\
\hline CSR Quality & $0.44^{*}$ & $0.38^{*}$ & -0.05 & $0.18^{*}$ & $0.57^{*}$ & $0.18^{*}$ & -0.10 & $-0.44^{*}$ & $0.32^{*}$ & $0.85^{*}$ & - \\
\hline
\end{tabular}

Note:

* Pearson correlation coefficient significant at $10 \%$. 
with net income, because of its accuracy in estimating the performance of real estate companies (e.g., Tsang, 2006). By analyzing the linear relationship of our second explanatory variable (Idiosyncratic Risk), we observe that this correlates negatively with size and FFO. This implies that real estate-specific financial performance is associated with lower levels of idiosyncratic risk and vice versa. The description of variables is shown in Exhibit 8.

\section{Methodology}

\section{Drivers of a Responsible Provision of Information}

Because $C S R_{i, t}^{\text {quality }}$ is an ordered categorical variable, we estimate the following latent regression via maximum likelihood as an ordered probit model with three categories, two threshold parameters, and without a constant: ${ }^{4}$

$$
\begin{aligned}
\text { CSR }_{i, t}^{\text {quality }} & =\beta_{1} \log \left(\text { Mval }_{i, t}+\beta_{2} \text { AuditFee }_{i, t}+\beta_{3} \log \left(\text { Emplo }_{i, t}\right.\right. \\
& +\beta_{4} \text { InfoRisk }_{i, t}+\beta_{5} \log \left(\text { Age }_{i, t}+\beta_{6} \log \left(\text { Volat }_{i, t-1}\right.\right. \\
& +\beta_{7} \text { ROA }_{i, t}+\beta_{8,9} \text { Region }_{i}+\beta_{10} \text { Year }_{t}+u_{i, t} .
\end{aligned}
$$

We expect the CSR intensity to increase for market value $\hat{\beta}_{1}$, our proxy for business complexity AuditFee $\hat{\beta}_{2}$, and human resources $\log \left(\right.$ Emplo) $\hat{\beta}_{3}$. Information risk is expected to be negative, $\hat{\beta}_{4}$, because it represents "the likelihood that firm-specific information that it is pertinent to investors pricing decisions is of poor quality," (Francis, Lafond, Olsson, and Schipper, 2005). We expect $\hat{\beta}_{5}$ to be statistically insignificant because experienced companies invest in CSR, just as unskilled companies. Therefore, business knowledge does not influence either the decision "to go CSR" or its intensity. Elevated levels of stock price volatility, the estimation risk, of the past period should enhance a firm's CSR strength in the next period and therefore $\hat{\beta}_{6}>0$. Financial performance should contribute to sustainable activities and their intensity, $\hat{\beta}_{7}>0.5^{5}$ Region and Year control for regional heterogeneity and time-varying effects. Our robustness check relaxes the assumption concerning the quality levels of CSR information by taking only the amount of information as dependent variable.

$$
\begin{aligned}
\text { CSR }_{i, t}^{\text {quantity }} & =\gamma_{1} \log \left(\text { Mval }_{i, t}+\gamma_{2} \text { AuditFee }_{i, t}+\gamma_{3} \log \left(\text { Emplo }_{i, t}\right.\right. \\
& +\gamma_{4} \text { InfoRisk }_{i, t}+\gamma_{5} \log \left(\text { Age }_{i, t}+\gamma_{6} \log \left(\text { Volat }_{i, t-1}\right.\right. \\
& +\gamma_{7} \text { ROA }_{i, t}+\gamma_{8,9} \text { Region }_{i}+\gamma_{10} \text { Year }_{t}+\pi_{i, t} .
\end{aligned}
$$

We estimate the model as a binary probit regression, taking into account that the transformation leads to a loss of information. Nevertheless, we expect the same effects as with equation 4 . 


\section{Consequences of Providing Responsible Information}

We study the consequences of enhanced responsible information provision on a firm's idiosyncratic risk $\Psi_{i, t+1}$. Idiosyncratic risk is defined as the error term between the estimated and predicted stock returns, estimated by the market model and scaled by the firm's total risk. We expect that, as the quality of CSR activities $C S R_{i, t}^{\text {quality }}$ increases, financial markets compensate for this strength through a reduction of the idiosyncratic risk.

$$
\begin{aligned}
\Psi_{i, t+1} & =\theta_{0}+\theta_{1} \log \left(M_{V a l}\right)_{i, t}+\text { Return }_{i, t}+\theta_{3} F_{F O} O_{i, t} \\
& +\theta_{4} \text { Sector }_{i}+\theta_{5} \text { CSR Ri,t }_{i, t}^{\text {high }}+\theta_{6} \text { CSR Ri,t }_{i, t}^{\text {low }}+\nu_{i, t}
\end{aligned}
$$

Consequently, we regress $\Psi_{i, t+1}$ on market value as a control for size, one year mean return, financial performance measured as FFO and control for real estatespecific sector variations. Concerning the error term, we estimate the regression assuming random effects for the iid error term $\nu_{i, t}$, in order to control for firms' unobserved heterogeneity. We expect $\hat{\theta}_{1}$ to be negatively related to idiosyncratic risk, because the size effect captures this variation observed by Fama and French (1992). According to Lee and Faff (2009), the higher the return, the higher the idiosyncratic risk $\hat{\theta}>0$. We control for FFO in order to proxy for the investors' perception of firm-specific real estate financial performance. Considering our CSR-variables, we expect a significant negative effect on the firm's idiosyncratic risk and $\left|\hat{\theta}_{5}\right|>\left|\hat{\theta}_{6}\right|$. The latter is the case, because $\hat{\theta}_{5}$ refers to a higher intensity of responsibility than $\hat{\theta}_{6}$, indicating that the greater the strength of responsible activities, the greater the reduction in $\hat{\Psi}_{i, t+1}$. We run a robustness check by relaxing the assumption of information quality and regress future idiosyncratic risk on both our control variables and $C S R_{i, t}^{\text {quantity }}$ :

$$
\begin{aligned}
\Psi_{i, t+1} & =\theta_{0}+\theta_{1} \log (M V a l)_{i, t}+\theta_{2} \text { Return }_{i, t}+\theta_{3} F_{F O} O_{i, t} \\
& +\theta_{4} \text { Sector }_{i}+\theta_{7} \text { CSR }_{i, t}^{\text {quantity }}+\varpi_{i, t} .
\end{aligned}
$$

In order to provide additional support to the hypothesis that a sustainability agenda in general does pay off, all else equal, we expect $\hat{\theta}_{7}$ to be negative, significant, and lower than $\left|\hat{\theta}_{5}\right|$.

Empirical Results

\section{Drivers of a Responsible Provision of Information}

Exhibit 5 presents the regression results of the factors that lead to an enhanced disclosure quality of socially responsible activities. The variance inflation factors 
Exhibit 5 | Drivers of a Responsible Provision of Information

\begin{tabular}{|c|c|c|c|c|c|c|c|}
\hline \multirow[b]{2}{*}{ Variable / Coefficient } & & \multicolumn{2}{|l|}{ Model 1} & \multicolumn{2}{|l|}{ Model 2} & \multicolumn{2}{|l|}{ Model 3} \\
\hline & & Coeff. & Z-Stat & Coeff. & Z-Stat & Coeff. & Z-Stat \\
\hline Log(MValue) & $\beta_{1}$ & 0.363 & $3.096^{* * *}$ & 0.512 & $4.744^{* * *}$ & \multirow[t]{2}{*}{0.403} & \multirow[t]{2}{*}{$3.472^{* *}$} \\
\hline Audit Fee & $\beta_{2}$ & 0.172 & $2.091^{* *}$ & 0.247 & $4.125^{* * *}$ & & \\
\hline Log(Employee) & $\beta_{3}$ & 0.366 & $3.725^{* * *}$ & & & 0.411 & $4.168^{* * *}$ \\
\hline Information Risk & $\beta_{4}$ & -12.640 & $-2.800^{* * *}$ & -8.185 & $-1.656^{*}$ & -12.227 & $-2.812^{* * *}$ \\
\hline Log(Age) & $\beta_{5}$ & -0.076 & -0.355 & 0.086 & 0.403 & -0.123 & -0.581 \\
\hline Log(Volatility) & $\beta_{6}$ & 0.705 & $3.397^{* * *}$ & 0.979 & $4.501^{* * *}$ & 0.641 & $3.013^{* * *}$ \\
\hline$R O A$ & $\beta_{7}$ & -1.946 & $-1.710^{*}$ & -1.422 & -1.139 & -2.322 & $-2.070^{* *}$ \\
\hline West Europe & $\beta_{8}$ & 1.235 & $2.952^{* * *}$ & 1.058 & $2.472^{* *}$ & 1.446 & $3.546^{* * *}$ \\
\hline Scandinavia & $\beta_{9}$ & 1.592 & $3.579^{* * *}$ & 1.788 & $3.939^{* * *}$ & 1.653 & $3.750^{* * *}$ \\
\hline Year Dummy & $\beta_{10}$ & \multicolumn{2}{|c|}{+} & \multicolumn{2}{|c|}{+} & \multicolumn{2}{|c|}{+} \\
\hline$\mu^{1}$ & & 5.000 & $3.134^{* * *}$ & 5.780 & $3.594^{* * *}$ & 5.606 & $3.721^{* * *}$ \\
\hline$\mu^{2}$ & & 5.800 & $3.612^{* * *}$ & 6.510 & $4.032^{* * *}$ & 6.393 & $4.219^{* * *}$ \\
\hline $\mathrm{n}^{*} \mathrm{~T}$ & & \multicolumn{2}{|c|}{160} & \multicolumn{2}{|c|}{160} & \multicolumn{2}{|c|}{160} \\
\hline Pseudo $\mathrm{R}^{2}$ & & \multicolumn{2}{|c|}{31.91} & \multicolumn{2}{|c|}{26.62} & \multicolumn{2}{|c|}{30.87} \\
\hline LogL & & \multicolumn{2}{|c|}{-112.884} & \multicolumn{2}{|c|}{-121.655} & \multicolumn{2}{|c|}{-114.597} \\
\hline F-stat & & \multicolumn{2}{|c|}{0.0000} & \multicolumn{2}{|c|}{0.0000} & \multicolumn{2}{|c|}{0.0000} \\
\hline$C S R_{i, f}^{\text {quality }}=0$ & & \multicolumn{6}{|c|}{75} \\
\hline$C S R_{i, f}^{q u a l i y y}=1$ & & \multicolumn{6}{|c|}{30} \\
\hline$C S R_{i, t}^{\text {quality }}=2$ & & \multicolumn{6}{|c|}{55} \\
\hline
\end{tabular}

Notes: The table uses a latent ordered probit regression approach. The dependent variable is CSR $R_{i, t}$ ality, which is a latent variable with three categories. Companies whose provision of responsible information is quantitatively high belong to the highest category. Companies disclosing only general information about their sustainable activities belong to the next category.

${ }^{*}$ Significant at the $10 \%$ level.

${ }^{* *}$ Significant at the $5 \%$ level.

*** Significant at the $1 \%$ level.

lie below 2.5 and signal no collinearity within the regressors. Model one indicates that as CSR information increases, the market value of the company increases as well. This result corresponds with previous research (Albers and Guenther, 2010; Gamerschlag, Moeller, and Verbeeten, 2010) and is significant at $\alpha=1 \%$. We are able to confirm that the intensity of socially responsible activities increases, ceteris paribus, whenever the number of employees increases, $\hat{\beta}_{3}$. Furthermore, the estimated coefficient for information risk $\hat{\beta}_{4}$ is negative: the greater the information risk, the lower the financial transparency and therefore the lower the CSR intensity. This result implies that, over 2007 and 2008, real estate companies 
intensified their CSR activities, which enhanced financial transparency. Therefore, it is important to establish this relationship and to consider financial transparency as a positive contributor to sustainable and responsible activities.

Our latent regression shows that the business experience $\hat{\beta}_{5}$, proxied by $\log ($ age $)$, does not enhance the probability to intensify CSR activities. Therefore, CSR is an innovative field that does not require extensive business knowledge. However, the estimated coefficient for stock price volatility $\hat{\beta}_{6}$ shows that enhanced estimation risk in the past year increases the probability of investing intensively in CSR activities in the present period. We do not predict a sign for business complexity $\hat{\beta}_{2}$. As Exhibit 5 shows, the more complex an enterprise's business model, the greater their efforts to invest in sustainability. This is important because it is logical to believe that complexity suppresses responsibility. We are able to show at $\alpha=1 \%$ that this is not in fact the case and that real estate companies invest in CSR, perhaps precisely because of the implied posterior benefits. The estimated coefficient of ROA $\hat{\beta}_{7}$ must be interpreted with caution. The $Z$-statistic of the predicted regression coefficient is low and insignificant in model two. This could be due to a negative impact of ROA on CSR, but the explanatory power of ROA is low. This result is confusing, because, as described theoretically, financial performance should enhance CSR. We regard this negative coefficient as a marketbased response of the "financially poor" years of 2007 and 2008. Nevertheless, our latent regression in model one has an explanatory power of $31.91 \%$, with 68 degrees of freedom.

Finally, we consider the regional differences by adding two dummy variables: West_Europe and Scandinavia. West_Europe takes a value of 1 for west Europe including the UK and Scandinavia. It is clear that the probability of achieving a more intensive level of sustainable activities is higher for Scandinavian real estate companies, than for all other countries $\hat{\beta}_{9}$. This result is in accordance with the survey of KPMG (2009), which indicates the advanced legal and reporting level these countries have concerning general sustainable reporting and GRI guidelines application.

The robustness check for our latent regression employs a probit estimation approach. Exhibit 6 shows that the estimated probit model is able to confirm increased business complexity $\hat{\gamma}_{2}$ and number of employees $\hat{\gamma}_{3}$ raises the probability of providing more general information concerning sustainable activities. It also shows that the regional differences are present and that enhanced stock price volatility influences CSR activities positively.

The coefficient of determination indicates an explanatory power of about $39.5 \%$. However, business transparency and financial performance are at $\alpha=10 \%$ and $\alpha$ $=5 \%$, which are both statistically insignificant. This indicates that the explanatory power of financial transparency influences the quality of information $\left(C S R_{i, t}^{\text {quality }}\right)$ rather than the amount of information $\left(C S R_{i, t}^{q u a n t i t y}\right)$.

\section{Consequences of Providing Responsible Information}

Our second research question concentrates on the effect of present enhanced information on sustainable activities, as well as its effect on future idiosyncratic 
Exhibit 6 | Drivers of a Responsible Provision of Information

\begin{tabular}{|c|c|c|c|c|c|c|c|}
\hline \multirow[b]{2}{*}{ Variable / Coefficient } & & \multicolumn{2}{|l|}{ Model 1} & \multicolumn{2}{|l|}{ Model 2} & \multicolumn{2}{|l|}{ Model 3} \\
\hline & & Coeff. & Z-Stat & Coeff. & Z-Stat & Coeff. & Z-Stat \\
\hline Log(MValue) & $\gamma_{1}$ & 0.403 & $2.842^{* * *}$ & 0.512 & $4.197^{* * *}$ & 0.505 & $3.959^{* * *}$ \\
\hline Audit Fee & $\gamma_{2}$ & 0.460 & $3.102^{* * *}$ & 0.438 & $3.377^{* * *}$ & & \\
\hline Log(Employee) & $\gamma_{3}$ & 0.308 & $2.787^{* * *}$ & & & 0.318 & $2.944^{* * *}$ \\
\hline Information Risk & $\gamma_{4}$ & -8.788 & -1.583 & -4.553 & -0.784 & -7.057 & -1.393 \\
\hline $\log (A g e)$ & $\gamma_{5}$ & -0.080 & -0.317 & 0.085 & 0.334 & -0.131 & -0.543 \\
\hline Log(Volatility) & $\gamma_{6}$ & 0.914 & $3.367^{* * *}$ & 1.085 & $3.900^{* * *}$ & 0.798 & $3.023^{* * *}$ \\
\hline$R O A$ & $\gamma_{7}$ & -1.576 & -0.981 & -1.283 & -0.778 & -2.893 & $-1.875^{*}$ \\
\hline West Europe & $\gamma_{8}$ & 0.969 & $2.051^{* *}$ & 0.864 & $1.853^{*}$ & 1.340 & $2.761^{* * *}$ \\
\hline Scandinavia & $\gamma_{9}$ & 1.469 & $2.801^{* * *}$ & 1.726 & $3.331^{* * *}$ & 1.639 & $3.103^{* * *}$ \\
\hline Year Dummy & $\gamma_{10}$ & \multicolumn{2}{|c|}{+} & \multicolumn{2}{|r|}{+} & \multicolumn{2}{|r|}{+} \\
\hline$n^{*} \mathrm{~T}$ & & \multicolumn{2}{|c|}{160} & \multicolumn{2}{|c|}{160} & \multicolumn{2}{|c|}{160} \\
\hline McFadden $\mathrm{R}^{2}$ & & \multicolumn{2}{|c|}{42.46} & \multicolumn{2}{|c|}{38.26} & \multicolumn{2}{|c|}{37.77} \\
\hline LogL & & \multicolumn{2}{|c|}{-63.748} & \multicolumn{2}{|c|}{-68.405} & \multicolumn{2}{|c|}{-68.941} \\
\hline F-stat & & \multicolumn{2}{|c|}{0.0000} & \multicolumn{2}{|c|}{0.0000} & \multicolumn{2}{|c|}{0.0000} \\
\hline$C S R_{i, t}^{q u a n t i t y}=1$ & & & & \multicolumn{2}{|c|}{83} & & \\
\hline \multicolumn{2}{|l|}{$C S R_{i f t}^{\text {qualiy }}=0$} & & & \multicolumn{2}{|c|}{77} & & \\
\hline
\end{tabular}

Notes: The table uses a bivariate probit regression approach. The dependent variable is CSR quantity, which measures the overall amount of information, with respect to the median, independent of the disclosure quality.

* Significant at the $10 \%$ level.

** Significant at the $5 \%$ level.

*** Significant at the $1 \%$ level.

risk for European real estate companies. We regress future idiosyncratic risk on the present CSR variables and control for size, one-year mean return, sectors, and real estate-specific financial performance. Exhibit 7 shows our estimation. Model 1 uses two dummy variables to measure for CSR, while model two employs only one and serves as our robustness check.

Our results indicate that higher returns positively influence idiosyncratic risk, although affects market value negatively. Higher FFOs lead to lower idiosyncratic risk. The estimated coefficient sign indicates that enhanced present financial profitability can reduce the variation between estimated and predicted return for real estate companies $\hat{\theta}_{3}$. By interpreting our coefficients for corporate social responsibility $\hat{\theta}_{5}$ and $\hat{\theta}_{6}$, we find statistically significant evidence that disclosure leads in the future to a decrease in idiosyncratic volatility for the ensuing years. This result holds only for firms that disclose profound key performance indicators, 
Exhibit 7 | Consequences of Providing Responsible Information

\begin{tabular}{|c|c|c|c|c|c|c|c|}
\hline \multirow[b]{2}{*}{ Variable / Coefficients } & & \multicolumn{2}{|l|}{ Model 1} & \multicolumn{2}{|l|}{ Model 2} & \multicolumn{2}{|l|}{ Model 3} \\
\hline & & Coeff. & $t$-Stat & Coeff. & $t$-Stat & Coeff. & $t$-Stat \\
\hline Constant & $\theta_{0}$ & 3.891 & $8.873^{* * *}$ & 3.847 & $8.810^{* * *}$ & 3.946 & $9.238^{* * *}$ \\
\hline Log(MValue) & $\theta_{1}$ & -0.196 & $-5.783^{* * *}$ & -0.189 & $-5.647^{* * *}$ & -0.197 & $-5.933^{* * *}$ \\
\hline Return & $\theta_{2}$ & 0.307 & $4.560^{* * *}$ & 0.303 & $4.501^{* * *}$ & 0.313 & $4.734^{* * *}$ \\
\hline FFO & $\theta_{3}$ & -0.009 & $-3.175^{* * *}$ & -0.008 & $-2.819^{* * *}$ & -0.008 & $-2.984^{* * *}$ \\
\hline REITS & $\theta_{4}$ & -0.236 & $-2.168^{* *}$ & -0.229 & $-2.134^{* *}$ & -0.233 & $-2.176^{* *}$ \\
\hline CSR High Quality & $\theta_{5}$ & & & -0.153 & $-2.436^{* *}$ & & \\
\hline CSR Low Quality & $\theta_{6}$ & & & -0.061 & -0.823 & & \\
\hline CSR Quantity & $\theta_{7}$ & & & & & -0.097 & $-1.683^{*}$ \\
\hline Hausman Test $(p-V)$ & & \multicolumn{2}{|c|}{$\chi^{2}=4.544(0.208)$} & \multicolumn{2}{|c|}{$\chi^{2}=4.762(0.446)$} & \multicolumn{2}{|c|}{$\chi^{2}=5.975(0.201)$} \\
\hline $\mathrm{n}^{*} \mathrm{~T}$ & & \multicolumn{2}{|c|}{160} & \multicolumn{2}{|c|}{160} & \multicolumn{2}{|c|}{160} \\
\hline Adj. $\mathrm{R}^{2}$ & & \multicolumn{2}{|c|}{27.11} & \multicolumn{2}{|c|}{29.26} & \multicolumn{2}{|c|}{28.51} \\
\hline F-stat & & \multicolumn{2}{|c|}{0.000} & \multicolumn{2}{|c|}{0.000} & \multicolumn{2}{|c|}{0.000} \\
\hline
\end{tabular}

Notes: The table is an OLS Regression with White diagonal standard errors. The dependent variable is Idio_Risk $(t+1)$, which measures the idiosyncratic risk for each asset derived from the market model following Ferreira and Laux (2007). It is calculated as the logarithm of the sum of square residuals divided by the explained sum of squares.

*Significant at the $10 \%$ level.

${ }^{* *}$ Significant at the $5 \%$ level.

${ }^{* * *}$ Significant at the $1 \%$ level.

goals achieved, and quantitative information, so that the firms are viewed as highly sustainable (i.e., high strength in terms of human rights, and social, environmental, and financial activities). Firms disclosing information on general activities and actions are not able to enjoy benefits in the next period. By analyzing our second model as our robustness check, we provide evidence that the overall strength $\hat{\theta}_{7}$, without taking the quality of the information into account, decreases the unexplained stock volatility, but the estimated coefficient of $C S R_{i, t}^{\text {quantity }}$ is lower than $\hat{\theta}_{5}$, which means that for the idiosyncratic risk mechanism, the quality of information plays a more important role than the quantity. Both quality and amount have a negative effect on idiosyncratic risk, but the latter has a weaker impact. Furthermore, the coefficient of determination explains approximately $28 \%$ of the system variation.

Consequently, these results indicate that firms disclosing CSR information are recompensed by the market, but these benefits are only exploited intensively by firms disclosing comprehensive CSR information, such as like the key indicators of $\mathrm{CO}_{2}$ emissions and energy consumption levels. 
Exhibit 8 | Variable Description

\begin{tabular}{|c|c|c|}
\hline Name & Abbreviation & Description \\
\hline Market Value & MVal & $\begin{array}{l}\text { Market value measured as the share price multiplied by the } \\
\text { number of ordinary shares in issue }[\mathrm{MV}] \text {. }\end{array}$ \\
\hline Audit Fee & Audit Fee & Expenditures for external auditing fees in $€$ [WC01801]. \\
\hline Age & Age & Number of months since inclusion to the stock market. \\
\hline Number of Employees & Emplo & Number of employees [WC07011]. \\
\hline Stock Price Volatility & Volat & 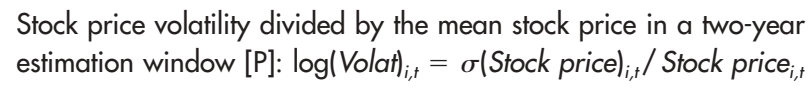 \\
\hline Return on Assets & $\operatorname{RoA}$ & Return on Assets in $€[$ WC08326]. \\
\hline Idiosyncratic Risk & IdioRisk & $\begin{array}{l}\text { Measured as logarithm of the sum of squared residuals divided by } \\
\text { the explained sum of squares from the one-factor market model, } \\
\text { using the one-month Euribor as risk-free rate and the individual } \\
\text { market return: } \Psi_{i, t}=\log \left(1-R_{i}^{2} / R_{i}^{2}\right)=\log (S S R / E S S) \text {. We } \\
\text { normalize the idiosyncratic volatility to the total volatility for each } \\
\text { asset, rather than by industry, because of the regional } \\
\text { heterogeneity of our sample. }\end{array}$ \\
\hline Funds from Operations & FFO & Firm-specific Funds from Operation in $€$ [WC04201]. \\
\hline CSR-Quality & $C S R^{q u a i l i t y}$ & $\begin{array}{l}\text { Latent variable taking the value of } 2 \text { if the provided CSR- } \\
\text { information is of high quantitative information; the value of } 1 \text { for } \\
\text { qualitative information and } 0 \text { for no information. }\end{array}$ \\
\hline CSR-Quantity & $C S R^{q u a n t i t y}$ & $\begin{array}{l}\text { Binary variable taking the value of } 1 \text { if the amount of provided } \\
\text { information is greater than the median, independently of the } \\
\text { quality of CSR information. }\end{array}$ \\
\hline CSR-High-Quality & CSR-High & $\begin{array}{l}\text { Binary variable taking the value of } 1 \text { for } C S R^{q u a l i t y}=2 \text { and } 0 \\
\text { otherwise }\end{array}$ \\
\hline CSR-Low-Quality & CSR-Low & $\begin{array}{l}\text { Binary variable taking the value of } 1 \text { for } C S R^{q u a l i t y}=1 \text { and } 0 \\
\text { otherwise }\end{array}$ \\
\hline West Europe dummy & West Europe & $\begin{array}{l}\text { Binary variable taking the value of } 1 \text { for Belgium, France, } \\
\text { Germany, Netherland, United Kingdom, and Austria. }\end{array}$ \\
\hline Scandinavia dummy & Scandinavia & $\begin{array}{l}\text { Binary variable taking the value of } 1 \text { for Finland, Norway and } \\
\text { Sweden. The reference category is Greece, Turkey, Italy, and } \\
\text { Switzerland. }\end{array}$ \\
\hline Information Risk & InfoRisk & $\begin{array}{l}\text { Standard deviation of the past four residuals of cross-sectionally } \\
\text { regressions: } \sigma\left(\hat{e}_{i, t}\right), t \in(t-4, \ldots, t) \text {. The higher the standard } \\
\text { deviation, the higher the information risks. Model following } \\
\text { Francis et al. (2005) controlled for country heterogeneity: } T C A_{i, t} / \\
T A_{i, t-1}=\alpha_{1} 1 / T A_{i, t-1}+\alpha_{2} C F O_{i, t-1} / T A_{i, t-1}+\alpha_{3} C F O_{i, t} / T A_{i, t-1}+ \\
\alpha_{4} C F O_{i, t+1} / T A_{i, t-1}+\alpha_{5} \Delta R E V_{i, t} / T A_{i, t-1}+\alpha_{6} P P E_{i, t} / T A_{i, t-1}+ \\
\alpha_{7,8} \text { Region }_{i}+e_{i, t} \text { Because our sample contains only real estate } \\
\text { firms, we add two dummy variables that control for regions, rather } \\
\text { than regressing for each industry sector. }\end{array}$ \\
\hline Total Current Accruals & $T C A$ & $\begin{array}{l}\text { Total current accruals calculated as } \Delta C A-\Delta C L+\text { StDebt }+ \\
\text { Depr. ( } \Delta \text { from } t-1 \text { to } t) \text {. }\end{array}$ \\
\hline
\end{tabular}


Exhibit 8 | (continued)

Variable Description

\begin{tabular}{|c|c|c|}
\hline Name & Abbreviation & Description \\
\hline Total Accruals & TAC & Total accruals calculated as TCA - Depr. \\
\hline Total Assets & $T A$ & Total current assets [WC02999]. \\
\hline $\begin{array}{l}\text { Cashflow from } \\
\text { Operations }\end{array}$ & CFO & Cashflow from operations calculated as NIBE - TAC. \\
\hline Revenues & REV & Revenues [WCO1001]. \\
\hline $\begin{array}{l}\text { Property, Plant and } \\
\text { Equipment }\end{array}$ & PPE & Property, Plant and Equipment [WC02301]. \\
\hline Current Assets & $C A$ & $\begin{array}{l}\text { Current Assets, calculated as [WC02651] - [WC02051] (Other } \\
\text { Assets - Receivables). }\end{array}$ \\
\hline Current Liabilities & $\mathrm{Cl}$ & $\begin{array}{l}\text { Current Liabilities calculated as [WC03351] - [WC02051] (Total } \\
\text { Liabilities - Current Liabilities). }\end{array}$ \\
\hline Short-term Debt & StDebt & Short-term Debt [WC03051]. \\
\hline Depreciation & Depr & Depreciation, Depletion, and Amortization [WC0 1 151]. \\
\hline $\begin{array}{l}\text { Net Income before } \\
\text { Extraordinary }\end{array}$ & NIBE & Net Income before Extraordinary [WC01551]. \\
\hline
\end{tabular}

Note: Codes in brackets represent the respective Worldscope Datastream Code.

\section{Conclusion}

After developing a survey in accordance to the guidelines from the GRI and EPRA, we measure the extent and intensity of sustainable activities of listed European real estate companies over 13 countries.

Our first research question reveals an increasing strength in CSR activities among European real estate companies, particularly among REITs. We conclude that CSR activities are influenced positively by market value, the number of employees, and auditing fees. Higher levels of financial transparency enhance the intensity and quality of socially responsible activities, whereas the probability of "going CSR" increases significantly for companies whose past stock price volatility is high.

Our second research question shows that ex ante CSR activities are rewarded by a reduction in unexplained stock variance (i.e., the idiosyncratic risk). Therefore, in order to exploit additional benefits, real estate companies should structure their CSR activities in such a way that clear signals are sent to capital markets. Furthermore, the greater the intensity and quality of ex ante CSR information, the lower the idiosyncratic risk. The analysis provides evidence that the overall strength in CSR activities is proportionally related to its benefits.

Our study is limited by the size of the sample. Nevertheless, we expect to expand our methodology by applying non-parametric models to identify possible non- 
linear effects and see the importance of this statistical field because of the lack of empirical results for real estate and sustainability. We believe that further investigations in this field should concentrate on the (possible) non-linear mechanism of CSR activities and financial performance. Furthermore, we are the first study, to our knowledge, a latent ordered probit regression model to investigate the drivers for a high provision of responsible information to capital markets.

\section{Endnotes}

1 www.snl.com; www.datastream.com.

${ }^{2}$ Leaving this implication behind, we found similar results, so that this assumption does not lead to incorrect inferences.

${ }^{3}$ Funds from Operations (FFO) are defined by Tsang (2006) as "an alternative (measure) to net income." Specifically, FFO is calculated "by adding back the net income the amount of depreciation and amortization related to real estate properties, gains and losses on the sale of real estate assets, and certain other unusual and infrequent specific accrual items."

${ }^{4}$ Estimation procedure excludes a constant, because the system would otherwise not be identifiable.

5 We also estimate equations 4 and 5 with FFO as a proxy for real estate financial performance and achieve the same results.

\section{References}

Aboody, D., J. Hughes, and J. Liu. Earnings Quality, Insider Trading, and Cost of Capital. Journal of Accounting Research, 2005, 43, 651-73.

Albers, C. and T. Guenther. Disclose or Not Disclose: Determinants of Social Reporting for STOXX Europe 600 Firms. Zeitschrift für Planung \& Unternehmenssteuerung, 2010, $21: 3,323-47$.

Bienert, S., C. Schuetzenhofer, G. Leopoldsberger, K. Bobsin, K. Leutgeob, W. Huettler, D. Popescu, E.-C. Mladin, R. Boazu, D. Koch, and D.-F. Edvardsen. Integration of Energy Performance and Life-Cycle Costing into Property Valuation Practice. IMMOVALUE. www.immovalue.org, 2010.

Davidson, R. and J. Mackinnon. Econometric Theory and Methods. New York: Oxford University Press, 2004.

Ecker, F., J. Francis, I. Kim, P.M. Ollson, and K. Schipper. A Returns-Based Representation of Earnings Quality. The Accounting Review, 2006, 81:4, 749-80.

Eichholtz, P., N. Kok, and J. Quigley. Why Companies Rent Green: CSR and the Role of Real Estate. Working Paper, University of California Energy Institute, 2009a.

—. Doing Well by Doing Good? An Analysis of the Financial Performance of Green Office Buildings in the USA. RICS Research, 2009b.

European Public Real Estate Association (EPRA). Best Practices Recommendations. Brussels: EPRA, 2009.

- EPRA Sustainability Reporting Committee. GRI CRESS Response and Proposal for EPRA BPR. 2010.

\begin{tabular}{l|l|ll} 
JOSRE & Vol. 3 & No. $1-2011$ \\
\hline
\end{tabular}


Falkenbach, H., A-L. Lindholm., and H. Schleich. Environmental Sustainability: Drivers for the Real Estate Investor. Journal of Real Estate Literature, 2010, 18:2, 203-23.

Fama, F. and K. French. The Cross-Section of Expected Stock Returns. Journal of Finance, 1992, 47, 427-65.

Ferreira, M. and P. Laux. Corporate Governance, Idiosyncratic Risk, and Information Flow. Journal of Finance, 2007, 62:2, 951-90.

Francis, J., I. Khurana, and R. Pereira. Disclosure Incentives and Effects on Cost of Capital around the World. Accounting Review, 2005, 80, 1125-62.

Francis, J., R. Lafond, P. Olsson, and K. Schipper. The Market Pricing of Accruals Quality. Journal of Accounting and Economics, 2005, 39, 295-327.

Fuerst, F. and P. McAllister. An Investigation of the Effect of Eco-Labeling on Office Occupancy Rates. Journal of Sustainable Real Estate, 2009, 1/1, 49-64.

- Green Noise or Green Value? Measuring the Effects of Environmental Certification on Office Values. Real Estate Economics, 2011, 39:1, 1-25.

Gamerschlag, R., K. Moeller, and F. Verbeeten. Determinants of Voluntary CSR Disclosure: Empirical Evidence from Germany. Review of Managerial Science, 2010, 4, 1-30.

Global Reporting Initiative. Sustainability Reporting Guidelines. GRI, Amsterdam, 2006.

Holder-Webb, L., J. Cohen, L. Nath, and D. Wood. The Supply of Corporate Social Responsibility Disclosures among U.S. Firms. Journal of Business Ethics, 2009, 84, $497-$ 527.

KPMG. KPMG-Handbuch zur Nachhaltigkeitsberichterstattung-Deutschlands 100 umsatzstärkste Unternehmen im internationalen Vergleich. 2009.

Lee, D. and R. Faff. Corporate Sustainability Performance and Idiosyncratic Risk: A Global Perspective. The Financial Review, 2009, 44, 213-37.

Luo, Y. and C.-B. Bhattacharya. The Debate over Doing: Corporate Social Performance, Strategic Marketing Levers, and Firm-Idiosyncratic Risk. Journal of Marketing, 2009, 73, 198-213.

Margolis, J., H. Elfenbein, and J. Walsh. Does It Pay to be Good? A Meta-Analysis and Redirection of Research on the Relationship between Corporate Social and Financial Performance. Mimeo, Harvard Business School, 2007.

Nelson, A., O. Rakau, and P. Doerrenberg. Green Buildings-A Niche becomes Mainstream. RREEF Research, 2010.

Orlitzky, M., F. Schmidt, and S. Rynes. Corporate Social and Financial Performance: A Meta-Analysis. Organization Studies, 2003, 24, 403-41.

Plumlee, M., D. Brown, and R.-S. Marshall. The Impact of Voluntary Environmental Disclosure Quality on Firm Value. Working Paper, University of Utah and Portland State University, 2008.

Porter, M. and M. Kramer. The Link between Competitive Advantage and Corporate Social Responsibility. Harvard Business Review, 2006, December, 78-92.

Roberts, C., D. Rapson, and D. Shiers. Social Responsibility: Key Terms and their Uses in Property Investment. Journal of Property Investment \& Finance, 2007, 25, 388-400.

Solow, R. Sustainability: An Economist's Perspective. Paper presented at the Eighteenth J. Seward Johnson Lecture to the Marine Policy Center, 1991.

Surroca, J., J. Tríbo, and S. Waddock. Corporate Responsibility and Financial Performance: The Role of Intangible Resources. Strategic Management Journal, 2010, 31, 463-90. 
Tsang, D. Comparing the Quality of Accruals for Alternative Summary Performance Measures in the Real Estate Investment Trust (REIT) Industry. Working Paper, AAA Financial Accounting \& Reporting Section (FARS), 2006.

We thank Nora Rothacher, Marina Bauer, Peter Geiger, Thomas Braun, and Anita Krajinovic-Bilos.

Marcelo Cajias, University of Regensburg, D-93953 Regensburg, Germany or marcelo.cajias@irebs.de.

Sven Bienert, University of Regensburg, D-93953 Regensburg, Germany or sven.bienert@irebs.de. 